Synthesis of PPAR Agonist via Asymmetric Hydrogenation of a Cinnamic Acid Derivative and Stereospecific Displacement of $S$-2-Chloropropionic Acid

Ioannis N. Houpis ${ }^{*}$, Lawrence E. Patterson, Charles A. Alt, John R. Rizzo, Tony Y. Zhang and Michael Haurez

Supporting Information

Table of Contents

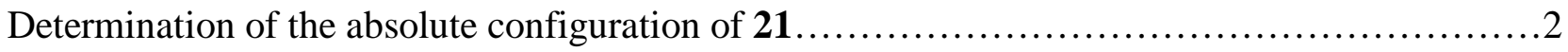

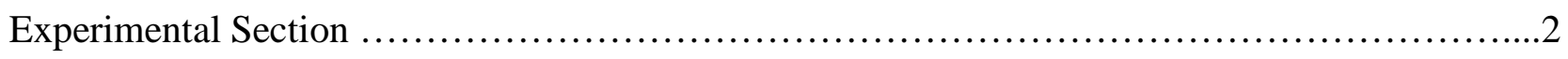

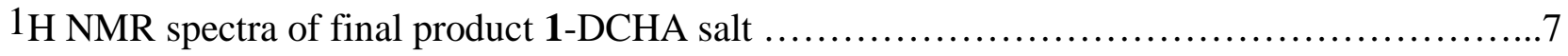

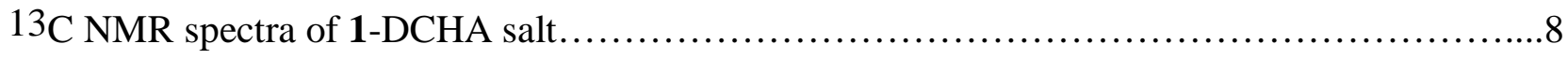

1H NMR spectra of 5- $R$-naphthyl ethyl amine salt....................................

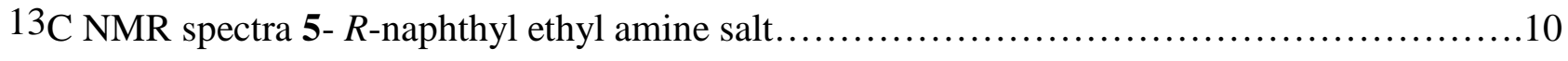

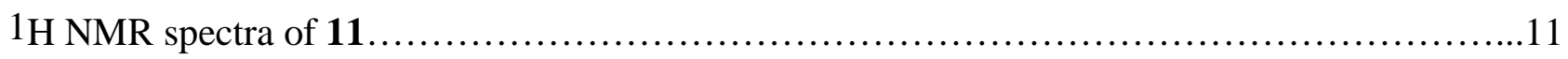

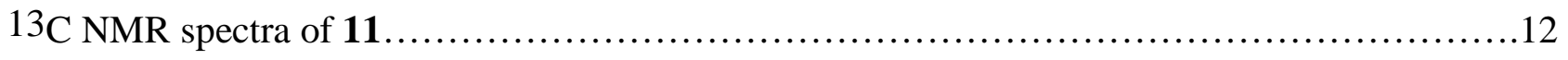

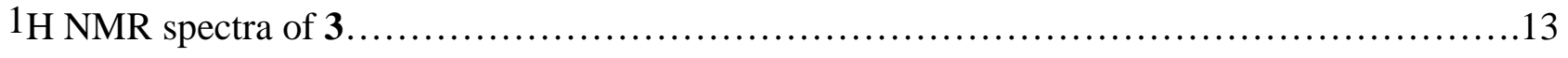

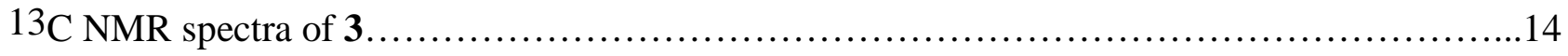

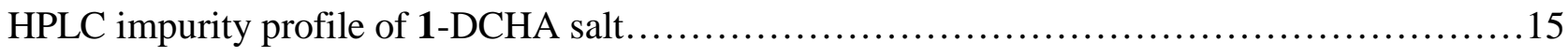

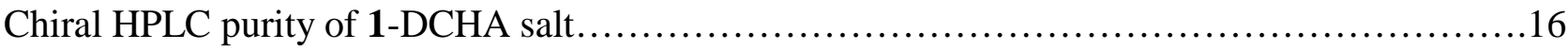




\section{Determination of the absolute configuration of 21:}

The stereochemistry at C-2 was established by X-ray crystallographic analysis of the D-alaninol salt of 21.

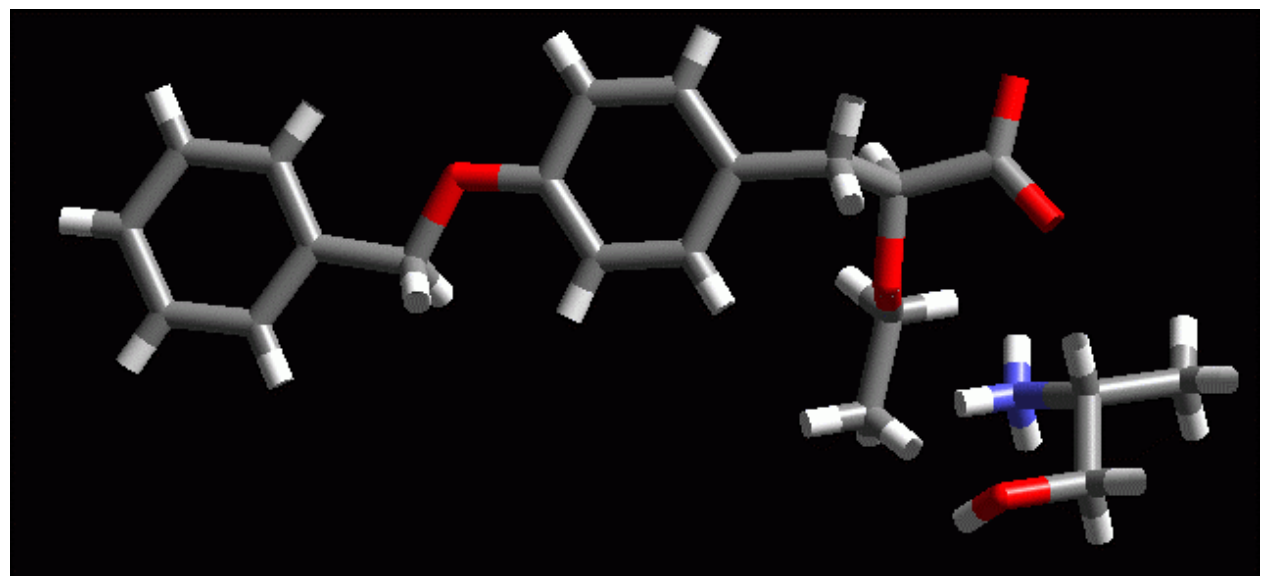

\section{Experimentals:}

\section{Synthesis of 2-ethoxy-3-(4benzyloxyphenyl)-acrylic acid 11}

A 22-L round bottom flask, equipped with thermocouple and pressure equalizing addition funnel under nitrogen, was charged with potassium tert-butoxide $(2.5 \mathrm{~L}$ of $1 \mathrm{M}$ solution in $\mathrm{THF})$ and cooled to $-40^{\circ} \mathrm{C}$. In a separate vessel, a solution was prepared consisting of 4-benzyloxybenzaldehyde (500 g, 2.36 mol) and ethyl ethoxyacetate $(342 \mathrm{~g}, 2.59 \mathrm{~mol})$ in THF (1.5L). The latter solution was added dropwise to the potassium tertbutoxide while maintaining the temperature at $-40^{\circ} \mathrm{C}$. The mixture was stirred for 1 hour at that temperature until the reaction was judged complete by HPLC analysis. Trifluoroacetic anhydride (439 g, 4.72 mol) was added dropwise at $-40^{\circ} \mathrm{C}$ while maintaining the temperature at $-40^{\circ} \mathrm{C}$ throughout the addition. At the end of 
addition, the mixture was allowed to warm to ambient temperature.The resulting brown solution, was treated with solid potassium tert-butoxide (639 g, 5.7mol). A substantial exotherm was observed which was allowed to raise the temperature to $60{ }^{\circ} \mathrm{C}$ and then maintained at this level for ca. 30 minutes to facilitate the elimination reaction. The reaction mixture was cooled to room temperature and treated with sodium hydroxide $(3 \mathrm{~L}$ of $5 \mathrm{~N}$ solution) overnight at ca 30 oC. Methyl $t$-butyl ether (MTBE) was added (10 L) and the mixture allowed to stir overnight. Precipitation of the Na salt was observed. heptane was added to further induce precipitation and the mixture was filtered to obtain $584 \mathrm{~g}$ of $\mathbf{1 1 - N a}$. Note that this is contaminated with Na trifluoroacetate. The free acid was isolated by dissolving the sodium salt in water $(5 \mathrm{~L})$ followed by addition of aqueous $\mathrm{HCl}(1 \mathrm{~N}$ solution) to $\mathrm{pH} 1$. The resulting solid was isolated and dried in vacuo at $50 \mathrm{oC}$ with a $\mathrm{N}_{2}$ sweep to give ca $490 \mathrm{~g}$ of the desired 11which was used without further purification. ${ }^{1} \mathrm{H}$ NMR $\left(400 \mathrm{MHz}, \mathrm{DMSO}-\mathrm{d}_{6}\right) \delta \mathrm{ppm}: 7.8(2 \mathrm{H}$, d), $7.4(5 \mathrm{H}, \mathrm{m}), 7.18(1 \mathrm{H}, \mathrm{s}), 7.0(2 \mathrm{H}, \mathrm{d}), 5.1(2 \mathrm{H}, \mathrm{s}), 4.0(2 \mathrm{H}, \mathrm{q}), 1.4(3 \mathrm{H}, \mathrm{t}) .{ }^{13 \mathrm{C}}\left(100 \mathrm{MHz}, \mathrm{DMSO}-\mathrm{d}_{6}\right), \delta \mathrm{ppm}:$ $15.85,66.98,69.75,115.39,122.88,126.81,128.06,128.37,128.93,131.84,137.34,143.73,159.18,165.88$. HRMS: cald: 298.3331, found: 298.1256.

\section{Synthesis of $S$-2-ethoxy-3-(4benzyloxyphenyl)-propionic acid acid 21}

The methanol was degassed by a subsurface nitrogen sparge. The reaction was run in an oxygen free environment using nitrogen as the inerting gas. A solution consisting of bis(norbornadiene)rhodium (I) tetrafluoroborate $(31.3 \mathrm{mg}, 0.0837 \mathrm{mmol})$ and SL-W001-1 (85.8 $\mathrm{mg}, 0.0922 \mathrm{mmol})$ in methanol $(15 \mathrm{~mL})$ was prepared in an Ace glass pressure vessel and stirred for 60 minutes at ambient temperature. A solution consisting of 3-(4-benzyloxyphenyl)-2-ethoxyacrylic acid (1.00 g, $3.4 \mathrm{mmol})$, sodium methoxide (18.1 mg, $3.35 \mathrm{mmol})$ and methanol $(15 \mathrm{~mL})$ was transferred by a double tipped needle to the Ace glass pressure vessel and pressured with hydrogen to 50 psi for 16 hours. The reaction mixture was concentrated to dryness. The residue was dissolved in diethyl ether $(50 \mathrm{~mL})$ and extracted with $1 \mathrm{~N}$ sodium hydroxide solution $(2 \mathrm{x} 50 \mathrm{~mL})$. The aqueous layers were combined and the $\mathrm{pH}$ adjusted to 1 using $5 \mathrm{~N}$ hydrochloric acid solution. The acidic aqueous solution was extracted with diethyl ether $(3 \times 25 \mathrm{~mL})$. The diethyl ether layers were combined, dried 
using sodium sulfate, and concentrated to give $0.790 \mathrm{~g}$ (78\%) of 3-(4-benzyloxyphenyl)-2-ethoxypropionic acid, which was found to be $92 \%$ ee by chiral capillary electrophoresis. The structural determination of this compound was performed by formation of the D-alaninol salt (isopropanol, $10 \mathrm{~mL}$ per gram, and 1 equivalent of D-alaninol at ambient temperature) and X-ray defraction analysis (see above and CIF files attached). Chiral capillary electrophoresis method: Capillary: $48.5 / 40 \mathrm{~cm}$ x $50 \mu \mathrm{m}$ uncoated. Conditions: temperature: $22^{\circ} \mathrm{C}$, volt: -20kV, detection: UV @ 214nm, injection volume: 10.0s @ 20.7 mbar, run buffer: 5\% HS- $\gamma$-CD, exit buffer: 5\% HS- $\gamma$-CD, preconditioning: 1.0 min with run buffer, post conditioning: 5.0 min with water, sample: 0.1 $\mathrm{mg} / \mathrm{mL}$ in $30 / 70$ methanol/water, run time 30.0 minutes. The desired enantiomer was observed at 26.85 minutes and the undesired enantiomer was observed at 28.55 minutes.

\section{Synthesis of $S$-2-ethoxy-3-[4-(R-1-carboxy-ethoxy)-phenyl]-propionic acid isopropyl ester 5}

A three neck round-bottom flask equipped with a condenser, a magnetic stir bar and a septum is dried with a heat gun and flushed with nitrogen. The phenol $5(10.20 \mathrm{~g}-40.4 \mathrm{mmol})$ was dried by azeotropic distillation with $3 \times 150 \mathrm{ml}$ of toluene and dried under vacuum with nitrogen flush for 2 hours. It was dissolved in $306 \mathrm{ml}$ of anhydrous THF and treated with TMSONa $(93 \mathrm{ml}, 93 \mathrm{mmol}$ of a $1.0 \mathrm{M}$ solution in THF) at ambient temperature. The clear pink reaction mixture is stirred at ambient temperature for $15 \mathrm{~min}$. The $S$-2-chloropropionic acid (3.7 $\mathrm{mL}, 42.4 \mathrm{mmol}$ ) was added to the reaction mixture in $5 \mathrm{~min}$. The resulting slurry was heated to $34^{\circ} \mathrm{C}$ and strirred at that temperature for 22 hours until complete as indicated by HPLC analysis. The reaction mixture is poured onto $300 \mathrm{~mL}$ of a $5 \%$ solution of $\mathrm{NaH}_{2} \mathrm{PO}_{4}$. The final $\mathrm{pH}$ was 5.9. The layers were separated and the organic layer was extracted consecutively with 300 and $200 \mathrm{~mL}$ of a saturated $\mathrm{NaHCO}_{3}$ aqueous solution. The aqueous layers were combined and $300 \mathrm{~mL}$ of fresh toluene were added. This mixture is acidified with $6 \mathrm{~N} \mathrm{HCl}$ to $\mathrm{pH}=$ 1.2. The layers are separated and the organic layer is dried over MgSO4 followed by filtration and evaporation to dryness. The crude yield is $96.8 \%$ by weight and the material was evaluated to be $94 \mathrm{w} / \mathrm{w} \%$ pure using as standard its phenethyl amine salt. The latter can be prepared as follows: The acid 5 (10.9 g) was dissolved in isopropyl acetate $(110 \mathrm{~mL})$ followed by $R$-naphthylethyl amine $(5.8 \mathrm{~g}, 34 \mathrm{mmole})$ and the mixture was stirred 
overnight. Filtration and washing of the salt with $i$-PrOAc afforded the salt 5a. ${ }^{1} \mathrm{H} \mathrm{NMR}\left(400 \mathrm{MHz}, \mathrm{CDCl}_{3}\right) \delta$ ppm: 1.02-1.15 (m, 9H), $1.19(\mathrm{~d}, \mathrm{~J}=6.32 \mathrm{~Hz}, 3 \mathrm{H}), 1.46(\mathrm{~d}, \mathrm{~J}=6.06 \mathrm{~Hz}, 3 \mathrm{H}), 2.63-2.83(\mathrm{~m}, 2 \mathrm{H}), 3.15-3.29(\mathrm{~m}$, $1 \mathrm{H}), 3.45-3.51(\mathrm{~m}, 1 \mathrm{H}), 3.68-3.77(\mathrm{~m}, 1 \mathrm{H}), 4.14-4.23(\mathrm{~m}, 1 \mathrm{H}), 4.94-4.99(\mathrm{~m}, 2 \mathrm{H}), 6.47(\mathrm{~d}, \mathrm{~J}=8.08 \mathrm{~Hz}, 2 \mathrm{H})$, $6.82(\mathrm{~d}, \mathrm{~J}=8.08 \mathrm{~Hz}, 2 \mathrm{H}), 7.34(\mathrm{t}, \mathrm{J}=7.58 \mathrm{~Hz}, 1 \mathrm{H}), 7.42-7.52(\mathrm{~m}, 2 \mathrm{H}), 7.69-7.81(\mathrm{~m}, 3 \mathrm{H}), 7.85(\mathrm{~m}, 1 \mathrm{H}), 7.90(\mathrm{br}$ s, 3H). 13C (100 MHz, CDCl3), $\delta$ ppm: 15.03, 18.48, 21.50, 21.78, 38.23, 46.60, 65.91, 68.23, 74.53, 80.29, $114.97,122.24,122.63,125.80,126.56,128.46,129.02,129.18,130.14,135.94,156.76,172.00,178.72$. HRMS: 325.1651, found 325.1644.

\section{Preparation of $S$-2-ethoxy-3-(4-\{R-1-[2-(4-ethyl-phenyl)-ethylcarbamoyl]-ethoxy $\}$-phenyl)-propionic} acid isopropyl ester:

Anhydrous THF (2.75 L), ethylphenethylamine (118.6 g) HOBT (127 g) and EDCI (90.2 g) were added to the toluene solution of 5 (above) between 20 and $30{ }^{\circ} \mathrm{C}$. After $15 \mathrm{~min}$, a second portion of EDCI (90.2 g) was added and the reaction mixture stirred at room temperature for $2 \mathrm{~h} . \mathrm{H}_{2} \mathrm{O}(1.15 \mathrm{~L})$ and $\mathrm{HCl} 37 \%(8.2 \mathrm{~g})$ were added to a pH of ca. 2. The layers were separated and the organic layer was washed with an aqueous solution of $\mathrm{NaCl}$ (10\% solution, $250 \mathrm{~mL})$, an aqueous solution of $\mathrm{Na}_{2} \mathrm{CO}_{3}(20 \%$ solution, $780 \mathrm{~mL})$ and finally with a second aqueous solution of $\mathrm{NaCl}(10 \%$ solution $250 \mathrm{~mL})$. The organic layer was partially distillated $(2.2 \mathrm{~L})$ under reduced pressure. Ethanol $(820 \mathrm{~mL})$ was added and a second distillation was performed (430 $\mathrm{g}$ of distillate) under reduced pressure Finally the ethanol volume was adjusted to $25 \mathrm{~mL}$ per gram of the product (determined by quantitative HPLC analysis) and the solution was used directly in the next step.

\section{Preparation of $S$-2-ethoxy-3-(4-\{R-1-[2-(4-ethyl-phenyl)-ethylcarbamoyl]-ethoxy $\}$-phenyl)- propionic} acid 1:

The solution of the ester above was treated with aqueous $\mathrm{NaOH}$ solution $\left(84 \mathrm{~g}\right.$ of $\mathrm{NaOH} / 2.1 \mathrm{~L}$ of $\left.\mathrm{H}_{2} \mathrm{O}\right)$ and the reaction mixture was strirred at 30 oC for 5 hours. The weight of the reaction mixture was $8.5 \mathrm{~kg}(3.29 \%$ $\mathrm{w} / \mathrm{w}=279.5 \mathrm{~g}$ of $\mathbf{1}$ ). The ethanol was partially distilled (direct aqueous work up did not succeed due to the large 
volume of ethanol present) and $\mathrm{H}_{2} \mathrm{O}(3.80 \mathrm{~L})$ and MTBE $(2.70 \mathrm{~L})$ were added to the residue. The aqueous phase is acidified with $\mathrm{HCl} 37 \%$ (ca. $200 \mathrm{~mL})$ to $\mathrm{pH}=2$ and extracted with MTBE $(2 \times 2.8 \mathrm{~L})$. The MTBE was partially evaporated under reduced pressure to give $5336 \mathrm{~g}$ of a solution of $\mathbf{1}(4.636 \% \mathrm{w} / \mathrm{w}=247.3 \mathrm{~g}$ of $\mathbf{1})$. The MTBE was removed in vacuo and replaced with isopropyl acetate $(2.5 \mathrm{~L}$, ca. $10 \mathrm{~mL} / \mathrm{g})$. The resulting homogeneous solution was treated with neat dicycloxexyl amine (109 g, 1.02 equiv.) at ambient temperature overnight. The resulting slurry was filtered, the filter cake washed with isopropyl acetate (300 mL) and dried in vacuo at 40 oC to afford 1 as the DCHA salt $(326 \mathrm{~g}, 92 \%) .{ }^{1} \mathrm{H} \mathrm{NMR}(400 \mathrm{MHz}, \mathrm{CDCl} 3) \delta \mathrm{ppm}: 1.09-1.35$ (m, $12 \mathrm{H}), 1.44-1.61(\mathrm{~m}, 7 \mathrm{H}), 1.69(\mathrm{~d}, \mathrm{~J}=10.86 \mathrm{~Hz}, 2 \mathrm{H}), 1.83(\mathrm{~d}, \mathrm{~J}=12.13 \mathrm{~Hz}, 4 \mathrm{H}), 2.07(\mathrm{~d}, \mathrm{~J}=11.12 \mathrm{~Hz}, 4 \mathrm{H})$, 2.60-2.76 (m, 3H), 2.77-2.86 (m, 1H), $2.91(\mathrm{dd}, \mathrm{J}=13.26,9.73 \mathrm{~Hz}, 1 \mathrm{H}), 2.96-3.12(\mathrm{~m}, 3 \mathrm{H}), 3.26-3.41(\mathrm{~m}, 1 \mathrm{H})$, 3.47-3.54 (m, 1H), 3.57-3.63 (m, 1H), 3.66-3.72 (m, 1H), 3.86 (d, J= 7.33 Hz, 1H), 4.57-4.7 (m, $1 \mathrm{H}), 6.54(\mathrm{t}, \mathrm{J}=$ $5.18 \mathrm{~Hz}, 1 \mathrm{H}), 6.78(\mathrm{~d}, \mathrm{~J}=7.33 \mathrm{~Hz}, 2 \mathrm{H}), 7.02(\mathrm{~d}, \mathrm{~J}=6.82 \mathrm{~Hz}, 2 \mathrm{H}), 7.12(\mathrm{~d}, \mathrm{~J}=7.07 \mathrm{~Hz}, 2 \mathrm{H}), 7.25-7.32(\mathrm{~m}, 2 \mathrm{H})$, 8.50 (s, 2H). ${ }^{13} \mathrm{C}\left(100 \mathrm{MHz}, \mathrm{CDCl}_{3}\right), \delta$ ppm: 15.23, 15.54, 18.85, 24.83, 25.25, 28.4, 29.30, 29.44, 35.28, $39.03,40.12,52.55,65.17,75.08,82.54,114.88,128.05,128.67,130.54,133.39,135.68,142.36,155.25$, 172.18, 177.57. HRMS: calc. 414.2280, found 414.2254 


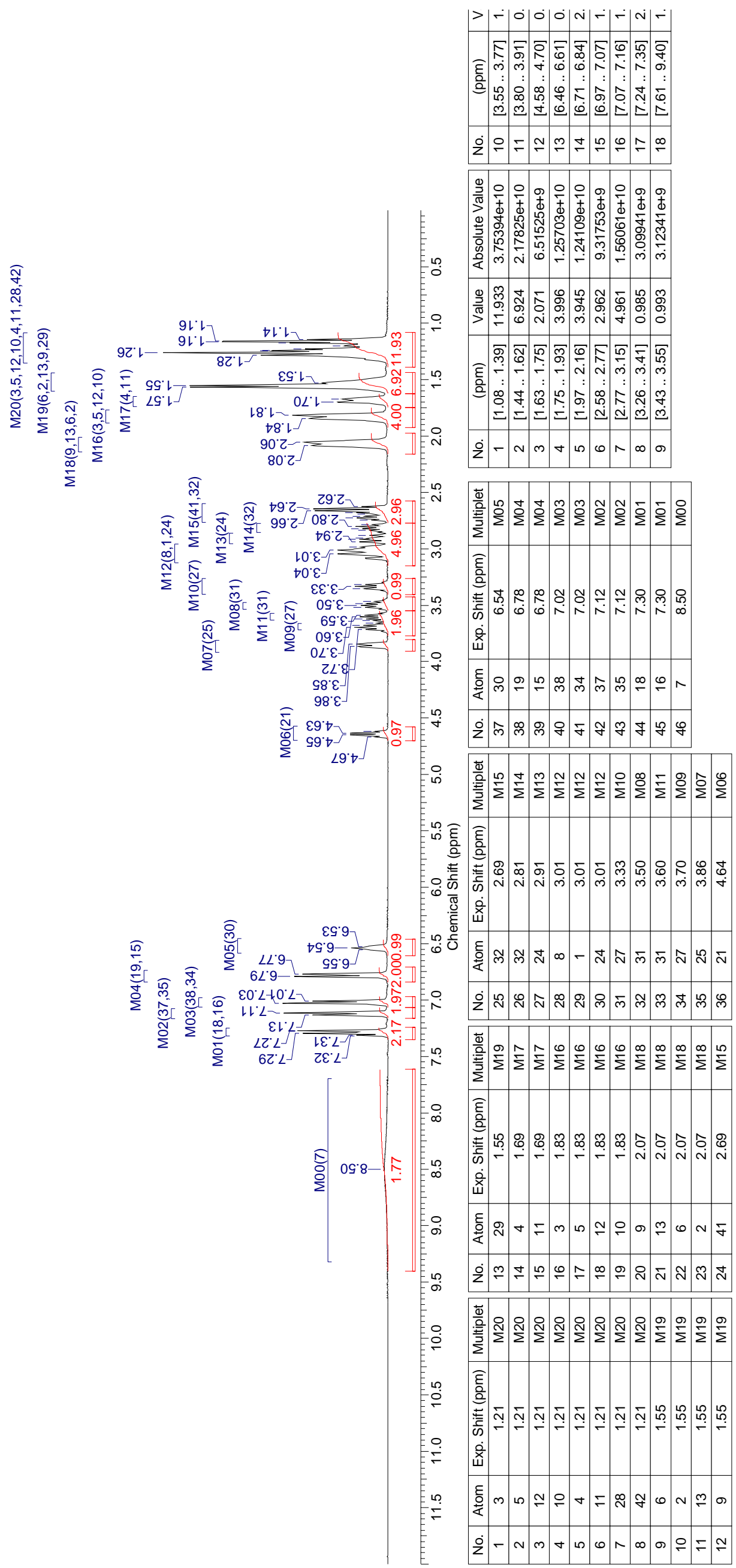



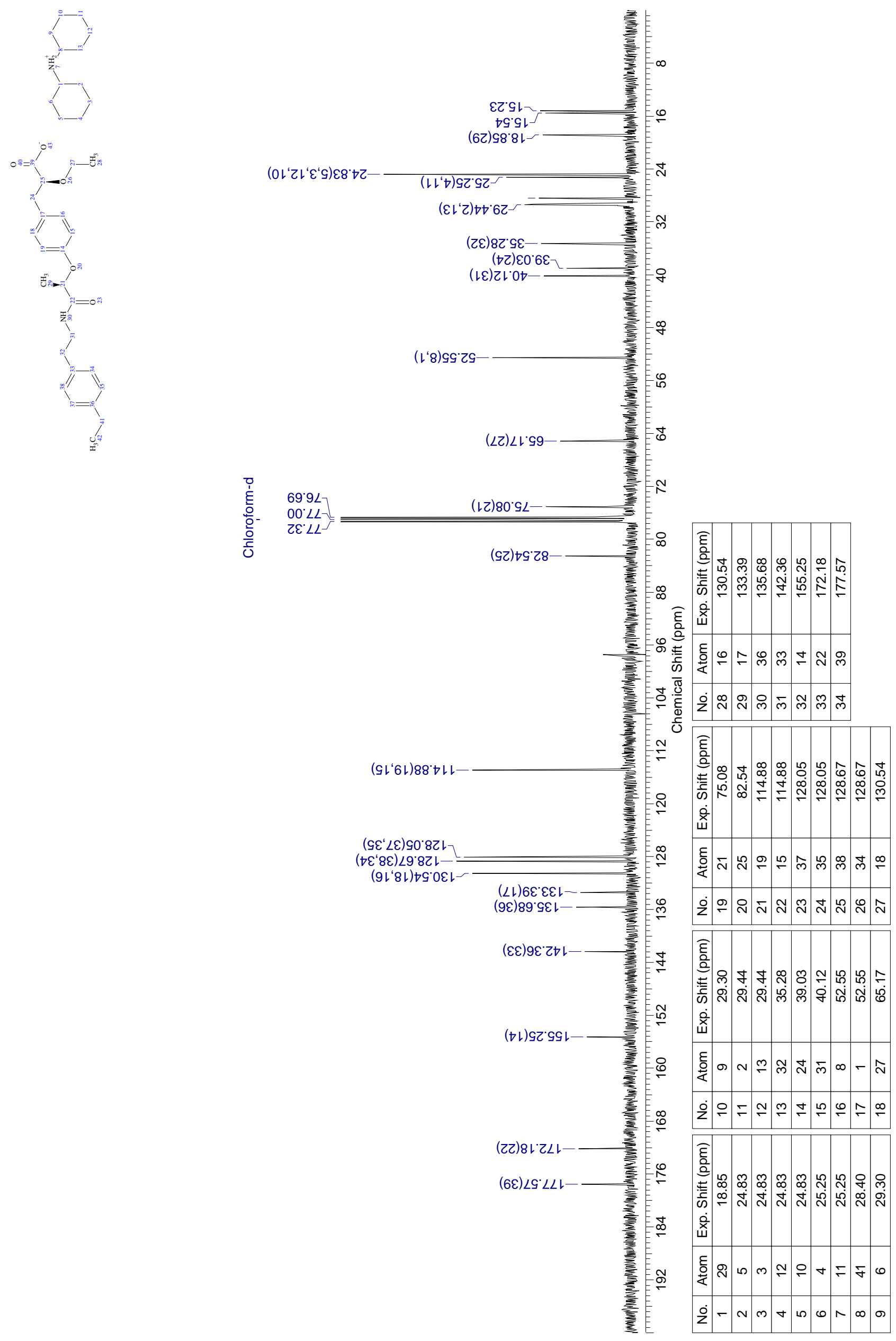

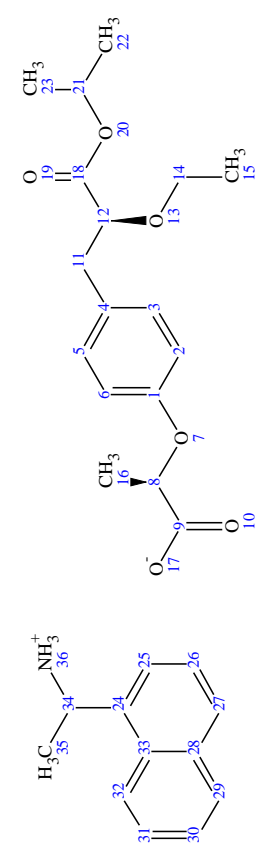

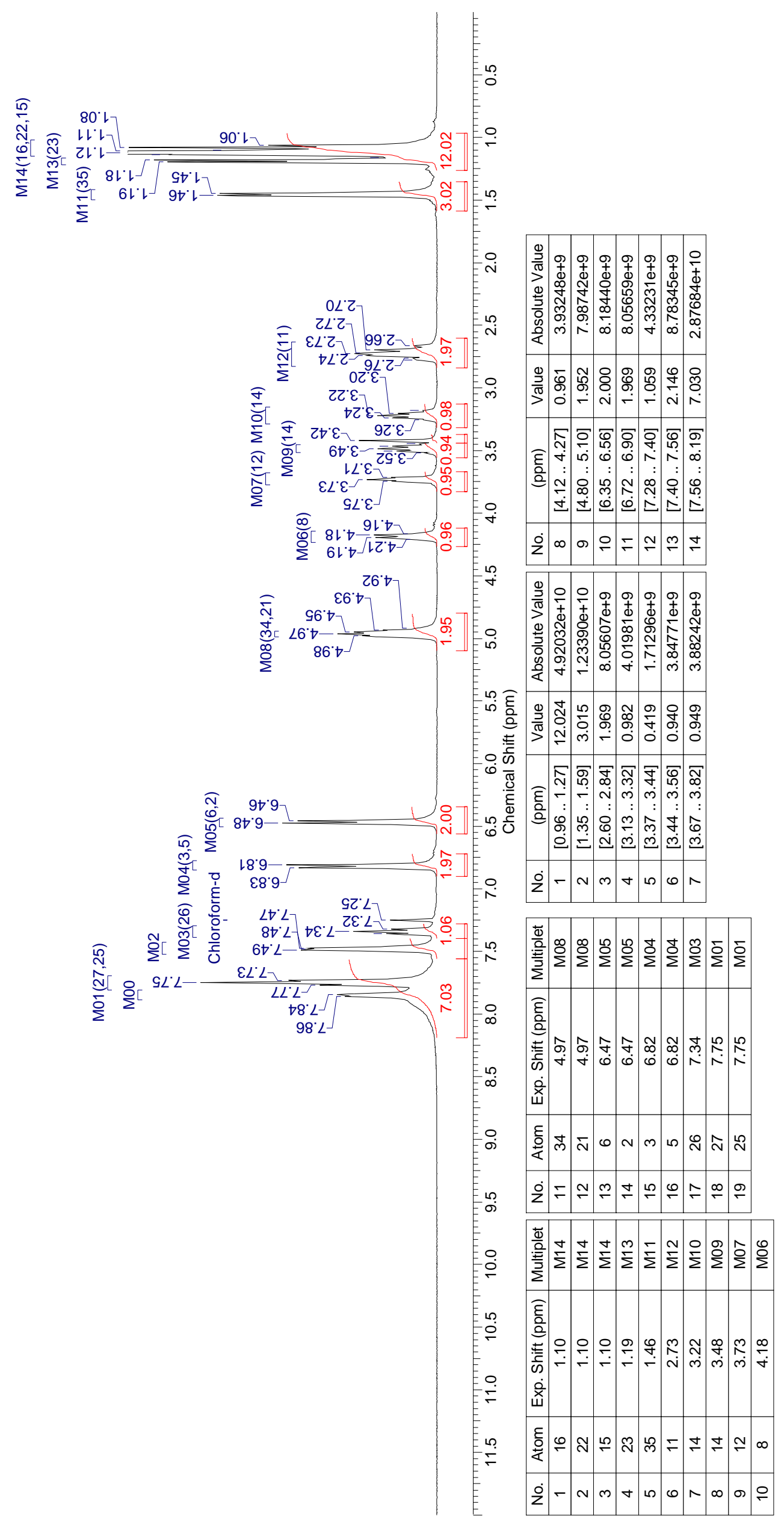



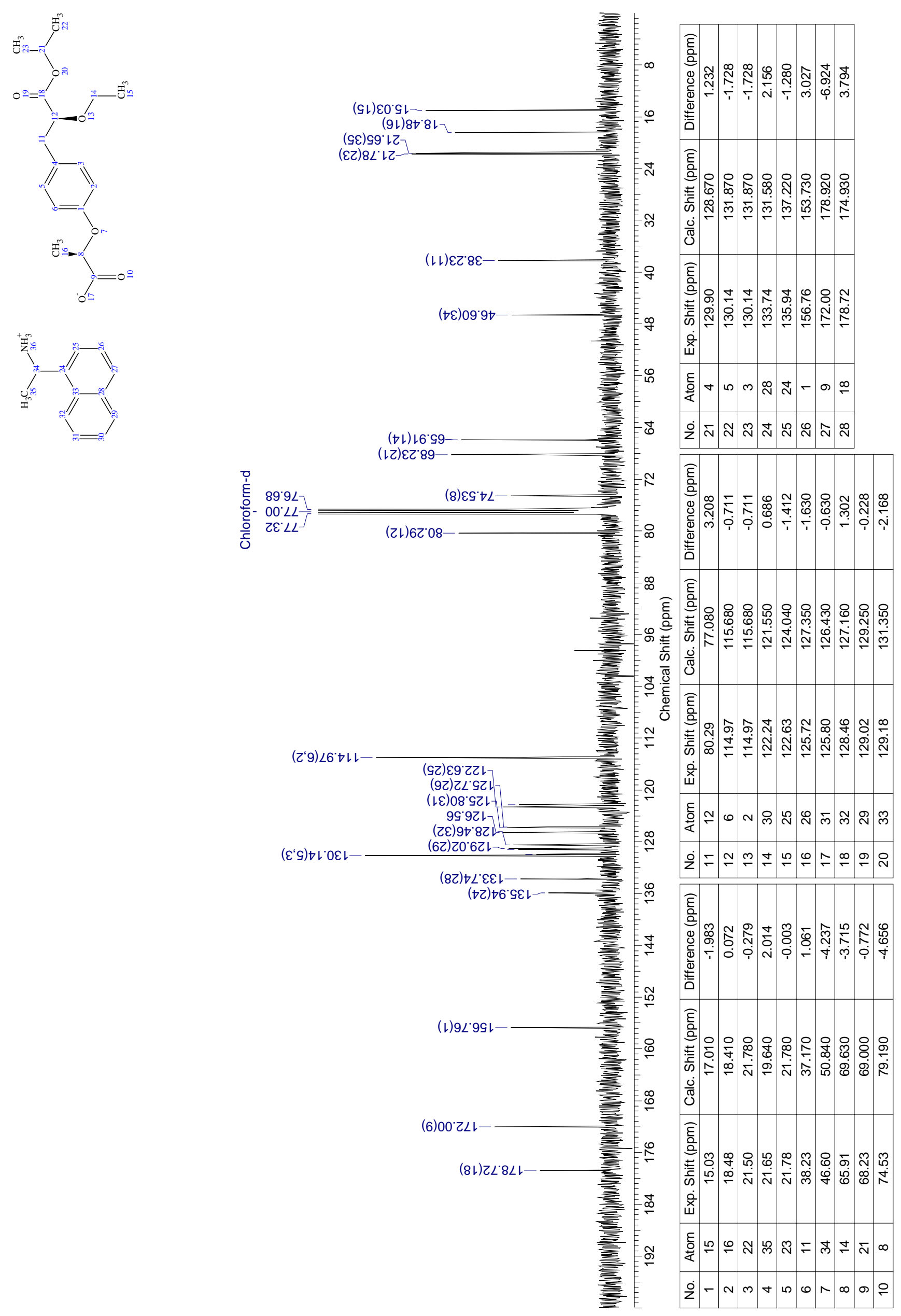


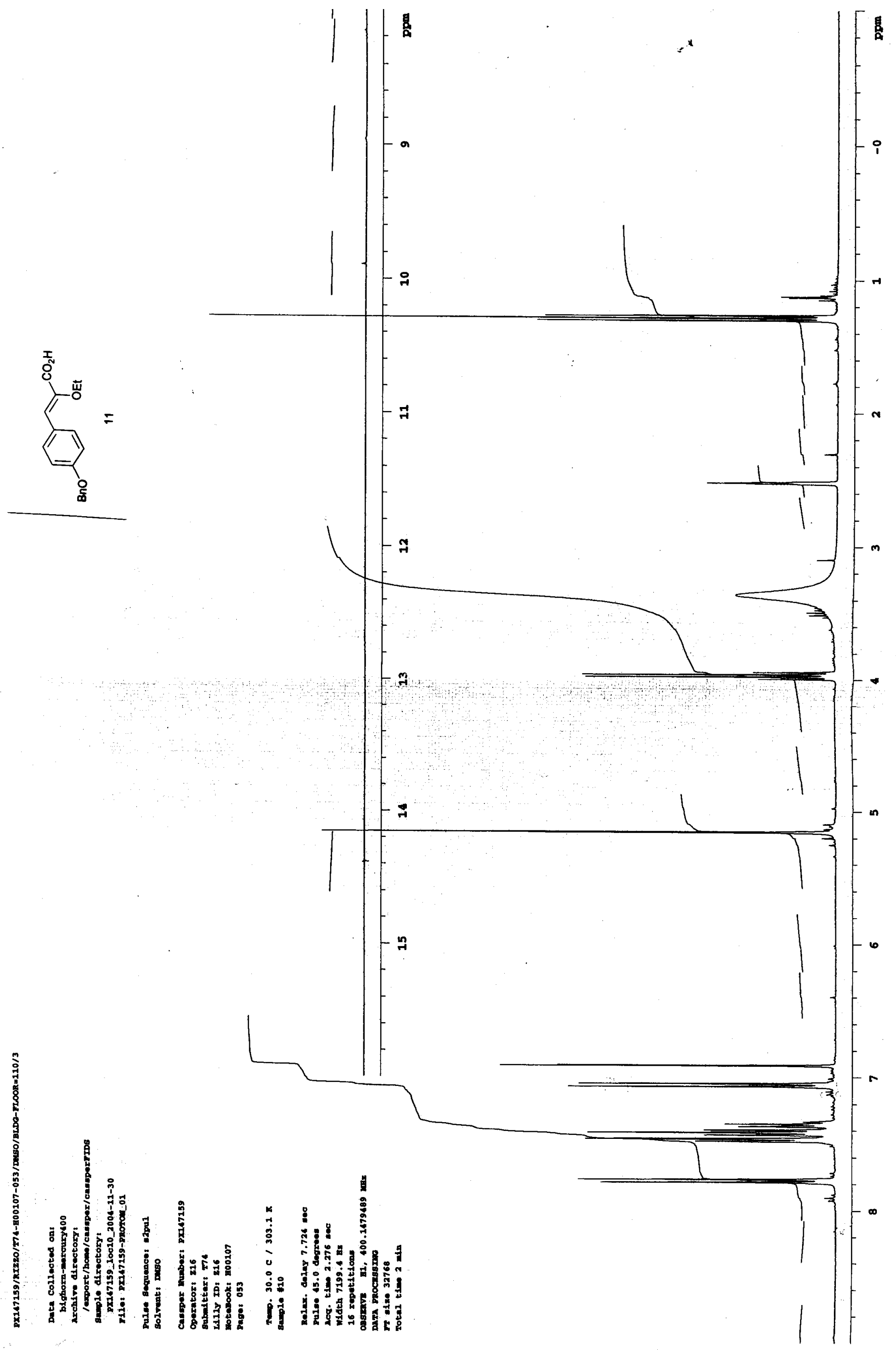




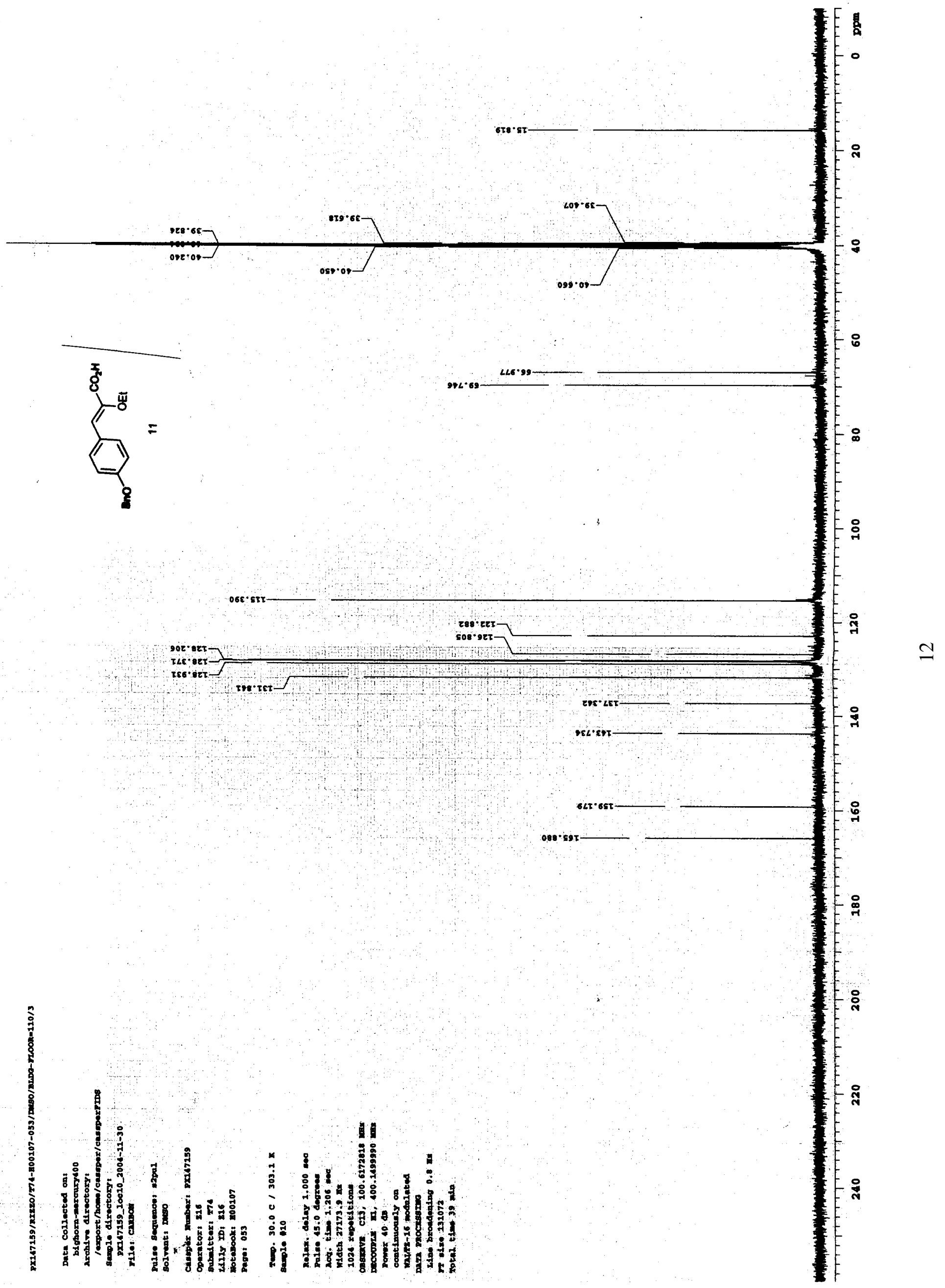



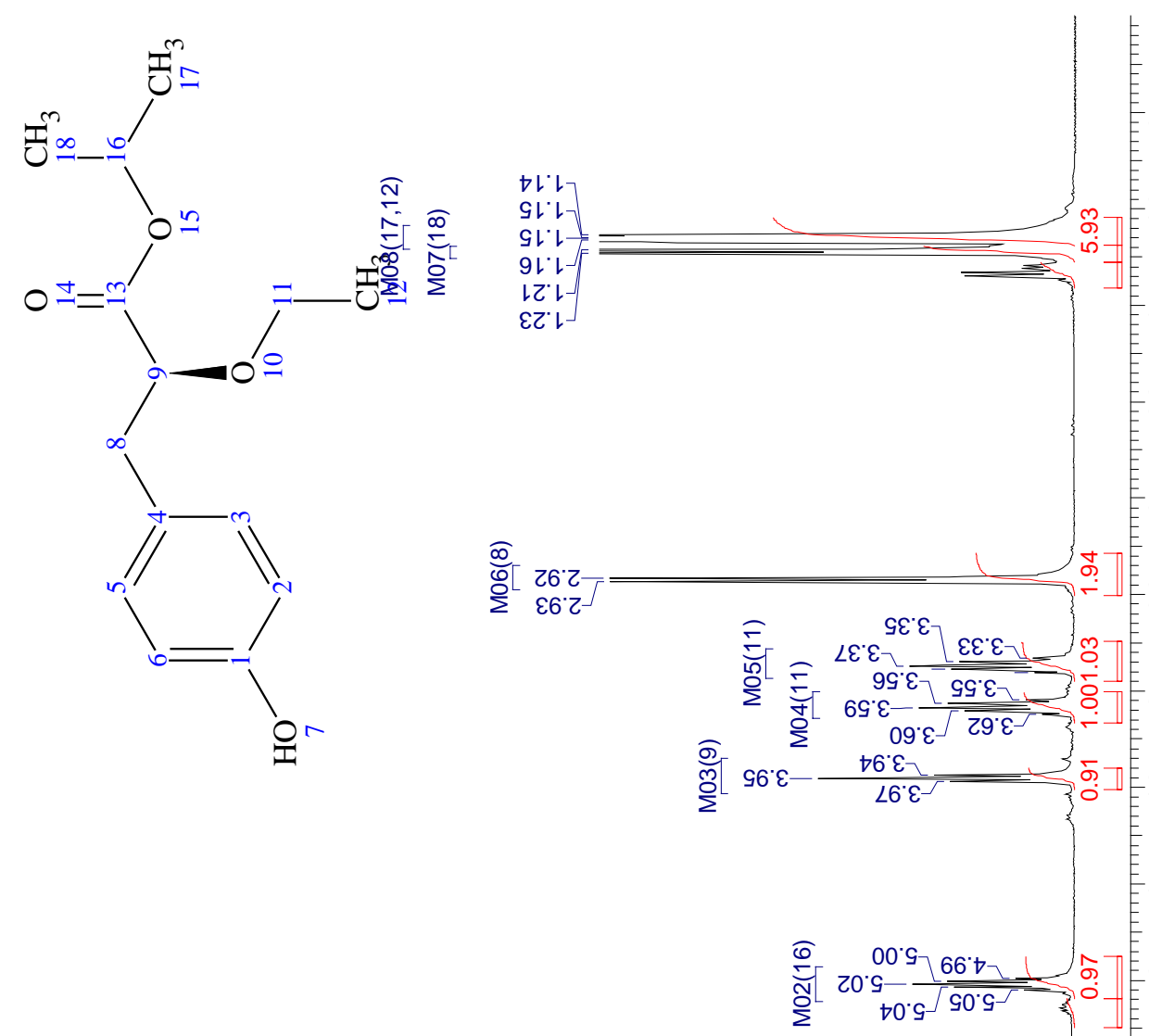

(1)

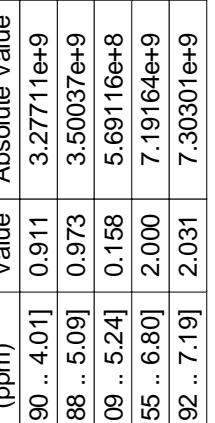

ஹூ

이 $\infty \propto 0=$

$\stackrel{2}{0}$

을으응ㅇㅇㅇㅇㅇ

$>0$

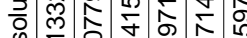

选

$=\ln \widehat{\varepsilon}$

@

$>$ 约 ف

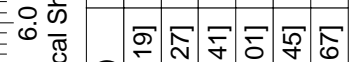

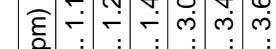

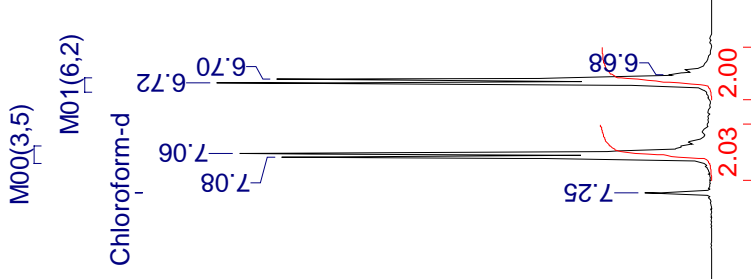

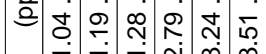

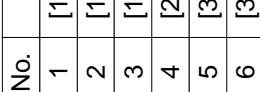

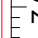

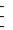

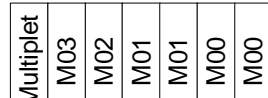

$\widehat{\mathrm{E}}$

$=\infty$

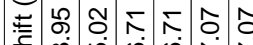

$=\infty \begin{gathered}\infty \\ =\infty\end{gathered}$

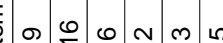

$=\stackrel{?}{\infty}$

ํํ $\infty \circ ㅇ ㅡ$

E응

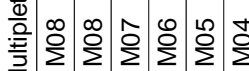

E

우

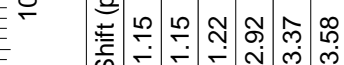

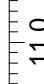

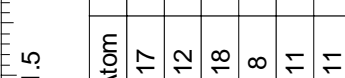

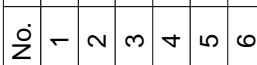



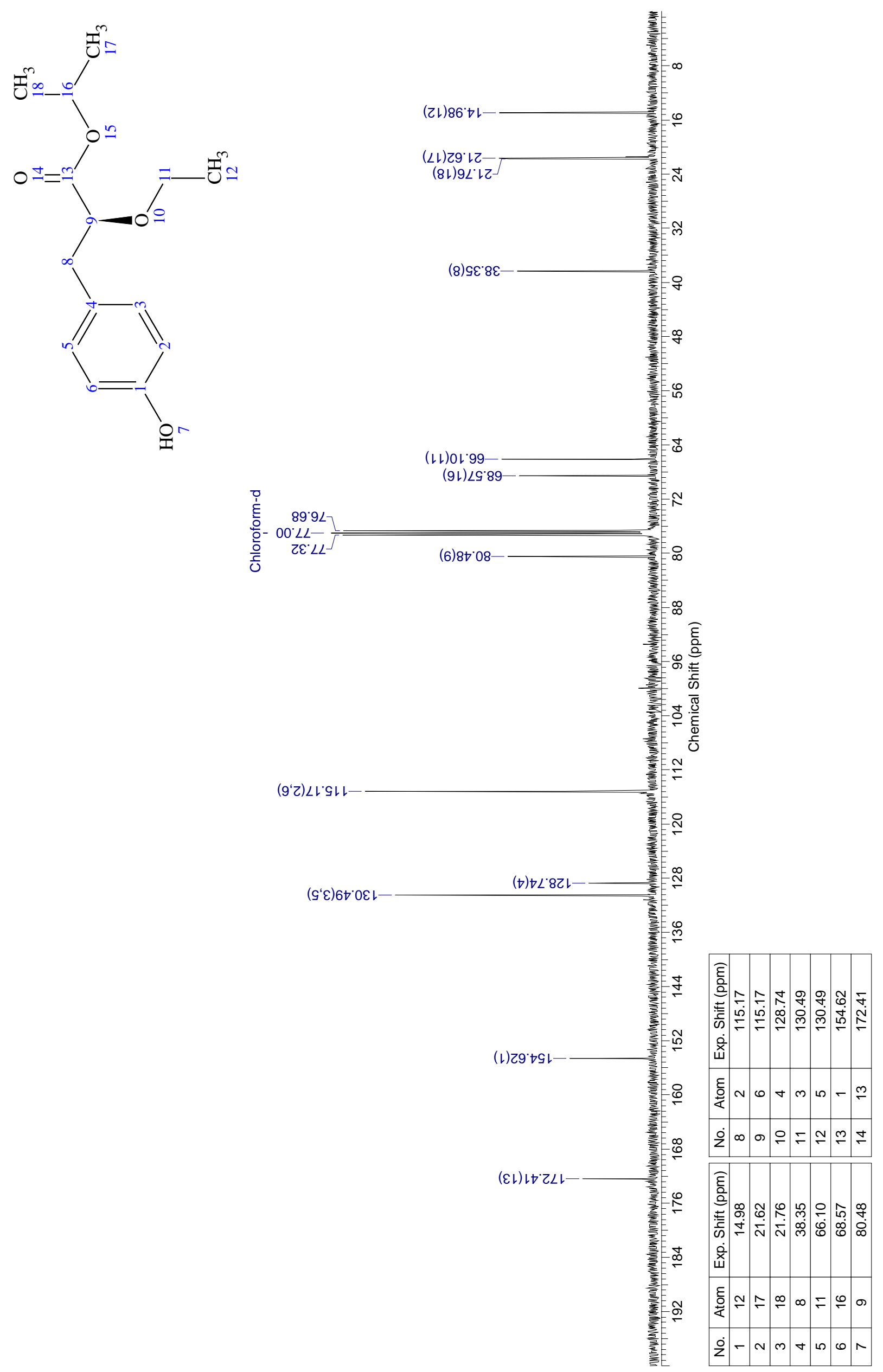


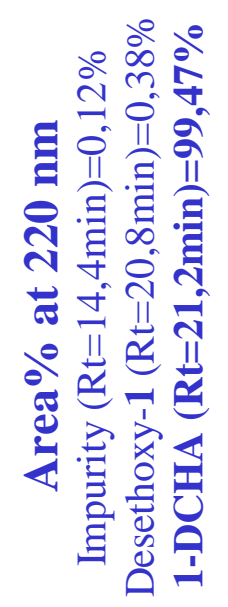




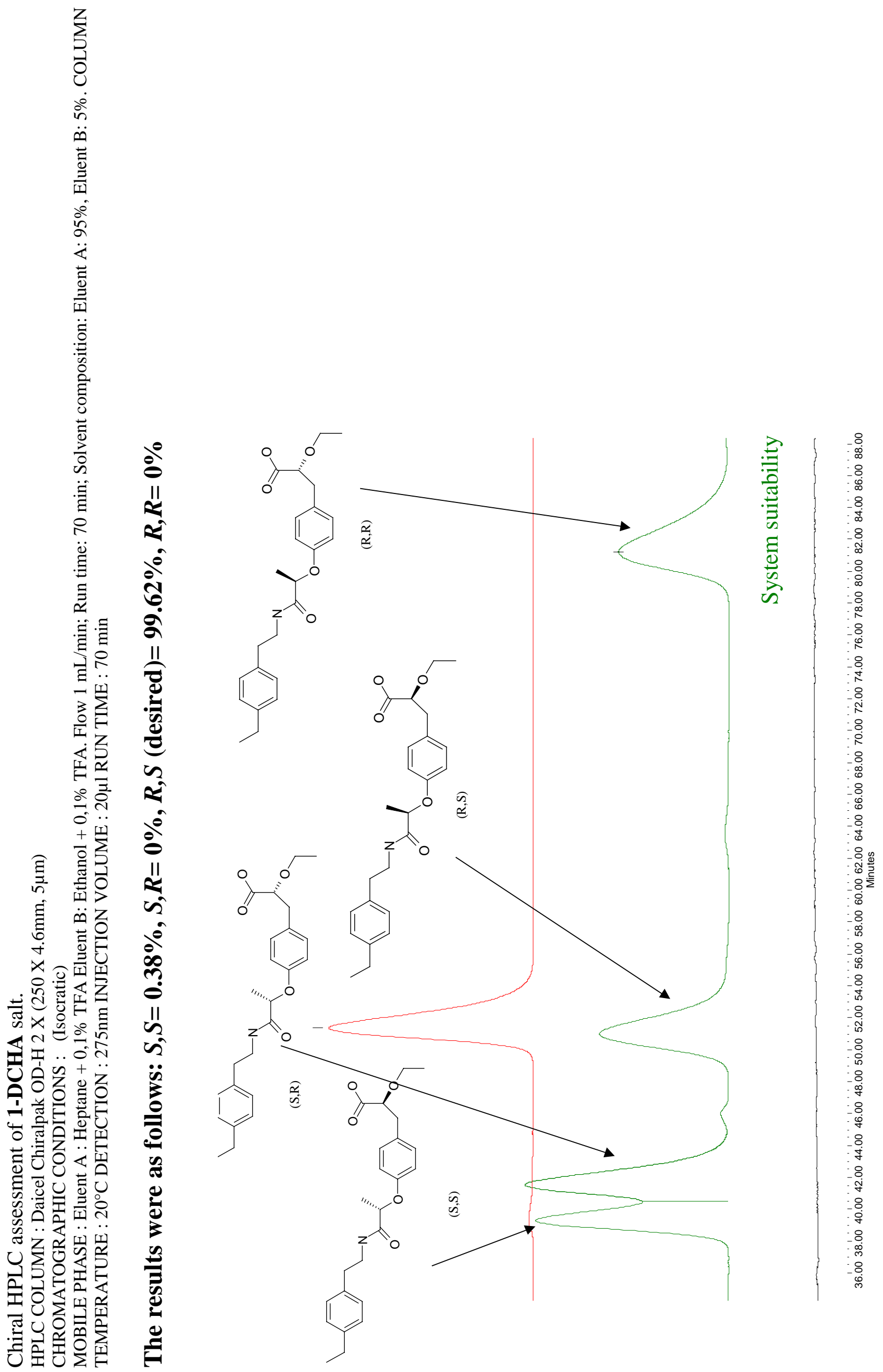

